\title{
POSING THE HISTORICAL JESUS QUESTION AND THE GOAL OF AFRICAN BIBLICAL SCHOLARSHIP
}

\author{
John Arierhi Ottuh* \\ http://dx.doi.org/10.4314/og.v11i 1.7
}

\section{Abstract}

Using the historical Jesus research method, the aim of this paper is to pose the Historical Jesus question in Africa and to enumerate the goal of African Biblical scholarship. The study showed that while the first quest sought to reconstruct the biography of Jesus from the New Testament materials in the $19^{\text {th }}$ century and separated the Jesus of the New Testament from the Jesus of history, the second quest in the $20^{\text {th }}$ century posed the question in terms of what, in the New Testament, can be attributed to the historical person of Jesus with some amount of certainty. Moreover, the third quest in the late $20^{\text {th }}$ century, posed the question of understanding Jesus as a human person among his contemporaries and sought to reconstruct the historical figure of the man Jesus against the background of the history, culture and society of first century Palestine and the Roman Empire. The study also showed that the goal of African Biblical scholarship has to do with: making the bible available for the ordinary readers; uncritical reading to critical reading of the Bible, faith building; impacting society; integration; bridging gaps; and evangelization. The paper also argued that the western method used from the experience of the enlightenment in posing the Historical Jesus question cannot build African Christianity; hence it becomes pertinent to build a Christology that is both scholarly and congenial with African Christian experience. The study recommended that African scholars be allowed to develop and pose the Historical Jesus question and answer contextually from an African Christian perspective and as such, it should also be accorded its rightful respect among committee of scholars.

\section{Introduction}

The life, ministry and personality of Jesus have been subjected to serious criticism by scholars since the $17^{\text {th }}$ century, some of which are western scholars. The thinking of these scholars and that of the 
church are not the same. While the church adopts the Jesus of the Bible (the New Testament) as an authentic historical figure and basis of the faith of the church such scholars like Schweizer and others like him on the other hand opine that the Jesus of the New Testament is a figment of the evangelist's imagination. The Enlightenment brought sweeping change to the world, and religious studies were no exception. Everything, even Jesus himself, fell prey to critical method and examination, and the current state of Jesus studies and Christology can be traced back to this fundamental change in the world's way of thinking (Burer, 2004).

Hermann Samuel Reimarus did not think in a vacuum when he did his research in his time because recent study has pointed to trends and periods earlier than the Enlightenment which influenced his thinking (Wright, 1996:13-16; McArthur, 1966:104). He was the first to give voice, however, to anything substantially different from the tradition and teaching received in the church throughout the seventeen and a half centuries before his writings were published, so he is seen as the starting point for modern critical study of Jesus (Burer). Using Reimarus as a starting point is now generally accepted as heuristically viable and useful. Wright also points out the inability of Reformation theology to adequately deal with the life of Jesus as a primary factor for setting the stage for Reimarus.

Using the historical Jesus Research as a method, the aim of this paper is to pose the Historical Jesus question in Africa and to enumerate the goal of African Biblical Scholarship. Within this context, the paper argues that the western method used from the experience of the aufklärung (enlightenment) in posing the Historical Jesus question cannot build African Christianity; hence it becomes pertinent to build a Christology that is both scholarly and congenial with African Christian experience.

\section{Theoretical Framework}

Many scholars have done a lot of work on the historical Jesus research both in the West and in Africa. The works of these scholars have become paradigm (model). Some of these scholars and their postulations will be used here as a theoretical frame work. Ukpong (2008) did a work on: "Historical Jesus Research in Anglophone 
Africa." Ukpong was a New Testament and Inculturation Theology scholar in the Catholic Institute of West Africa, Port Harcourt, and University of Uyo before his demise on 6 December, 2011. Ukpong postulates that the quest for the historical Jesus belongs within the tradition of the historical critical method which is currently a major sector of modern western biblical scholarship, and remains perhaps the most engaging and at the same time daunting task of this branch of biblical scholarship. In a broad sense, it has to do with understanding Jesus of the New Testament against his first century $\mathrm{CE}$ context. This involves the question of the relationship between the historical figure of Jesus and the Christ of the New Testament, the object of the Christian faith. It concerns Christian origins, the clarification of the historical foundation of the Christian faith. Therefore, it is a question of fundamental importance to Christianity that claims to be based on a historical person, Jesus, not a mythical figure. Ukpong explained further that in Africa, two main streams of biblical scholarship are current. One follows the Euro-American pattern that combines the search for truth with a professed commitment to scientific objectivity, and seeks to discover the objective meaning of biblical texts. To him, this is not very common. The other is contextual method and that this contextual method consciously links the understanding of biblical texts to specific concrete contexts, and establishes creative encounters between them in a way that consciously and explicitly brings the present context into the process of interpretation and that in it, the Bible is read, not for arriving at universal principles but for responding to faith questions and clarifying Christian commitment and practice in concrete life situations. The approach ensures that specifically African issues and interests constitute the key factors that shape the agenda of biblical scholarship in Africa. It also mediates Africa's specific contribution to global biblical research and as such, most of African historical Jesus scholarship seeks to understand Jesus not only against his first century background but also in terms of the contemporary African contexts.

Elenga (2002) a Jesuit from Congo-Brazzaville who did his graduation in the Weston School of Theology in the USA, gives a summary account of the various aspects of African Christology, the principles used to develop it through a simultaneous attention to 
African anthropology and culture and the data of revelation, and how this theology enriches and relates to the received formulations of faith. Elenga asserts further that in Christology, ecclesiology, biblical theology or other areas, African theology offers material for discussion and reflection which cannot be neglected. Elenga argues that African descriptive Christologies encapsulate the recapture of Jesus, his deeds, his images and the understanding people have of him and as such, most of African christologies work in a frame that is characterized by contextualization, relation, and re-appropriation. In so doing, they take the traditional presentations of Jesus for granted, and do not face the tension between the humanity and the divinity of the man of Galilee. Elenga treated this in three sections. First, relocating the manifestation of the Jesus research, second, to define the conditions and methods generally used in African Christologies and third, propose a defining parallel between these Christologies and the loci of credibility and relevance as suggested by Haight (1999:47-51).

Loba-Mkole (2005) used Luke 22:69 and Acts 7:56 as a model in approaching intercultural exegesis of the term "Son of Man" from two perspectives: that of a biblical culture in the first century Graeco-Roman world, and that of a current Christian culture in Africa. The study concludes that the "Son of Man" concept in Luke 22:69 and Acts 7:56 did not only include a reference to the eschatological saviour, judge and defender, but also create a sense of Jesus' solidarity with his fellow human beings and such, such an understanding would certainly have led to Jesus' exaltation by his followers, who lived under conditions of social turmoil in the Graeco-Roman world of the first century, and would lead to such an exaltation by those who experience similar circumstances in Africa today. In the same vein, Loba-Mkole (2008) in his study on "Rise of intercultural Biblical exegesis in Africa" documents the rise and development of intercultural Biblical exegesis in Africa, especially with regard to New Testament interpretations of which he argues that new exegetical tool was launched in 1996, when Justin Ukpong published an article introducing and applying the method of inculturation Biblical hermeneutic. He reminiscents that in $1998 \mathrm{~J}$ B Matand, with no reference to Ukpong, embraced this method, which 
through the books of C.N.A Cilumba and U.C. Manus, published respectively in 2001 and 2003, evolved into intercultural Biblical exegesis/hermeneutics. Loba-Mkole attempted to contribute to knowledge by enhancing the inculturation method of biblical hermeneutics by focusing on intercultural Biblical exegesis. In his work, the first section dwelt on the different trends of Biblical exegesis in Africa and the second section handled the different phases of intercultural exegesis. Jean-Claude Loba-Mkole, STD, $\mathrm{PhD}$ (Leuven), is a lecturer at Hekima College and translation consultant with the United Bible Societies (Nairobi).

Okure (2011) contributes that right from the second Vatican Council, Christianity moved from being a largely Hellenistic Jewish religion to becoming a world religion and this has manifested in the historical Jesus research in a global context. Okure's work seeks to appropriate Jesus and relate His meaning to their lives and world, for the name Jesus means Yeshua in the Hebrew language (Matt.1:21). To Okure, if it is accepted that recipients of the good news of Jesus of Nazareth are themselves part of the historical Jesus research, when this research is placed within the optic and scope of biblical revelation, then such research requires us to observe how Christianity today continues the process of receiving (hearing the proclamation), accepting (believing), appropriating (living according to the Christ received), and transmitting (proclaiming) this same historical Jesus. This transcends race, colour, sex, age, profession and so forth. This makes Jesus more accessible to people of all cultures and location. Sis. Theresa Okure is a New Testament Professor at the Catholic Institute of West Africa, Nigeria.

Keener (2011) agree that presuppositions of one sort or another are inevitable, but one way to control our assumptions in the interest of common dialogue is to consider how we would read the Gospels if they were not texts used by a current world religion and that the majority of Gospels scholars see the Gospels as ancient biographies. Although ancient biographies varied in their historiographic practice, in the early Empire biographies about figures who lived in the generation or two before the biographer included substantial historical information about the figure. In Keener's view, this observation may be particularly relevant for biographies about sages. Moreover, he opines that schools often 
preserved considerable information about their founders' teachings; ancient memory practices exceeded what is typical today, and disciples often preserved and passed on considerable information and as such researchers should neither treat the Gospels more skeptically nor demand from them greater precision than we would from comparable works of their era. Keener seems to presuppose that if the biographies of ancient school founders were preserved by their disciples (students), the disciples, vis a vis the gospel writers must have kept a true biography of Jesus as well.

Craig S. Keener is a North American academic and professor of New Testament at Asbury Theological Seminary.

Charlesworth (2011) revealed that a new study of Jesus began about 1980. In contrast to the previous study of Jesus it is not confessional or theologically motivated. It seeks to ask questions using the highest form of scientific precision and honesty. Some results are disappointing, others are possible or probable. Experts in Jesus research are not expected to agree but to discuss methods and conclusions, and in the process, by keeping an eye on questions, to improve research.

From a philosophical point of view Miller (2014) using epistemological humility and methodological naturalism as a paradigm for the study of the historical Jesus, opined that epistemological humility proper to methodological naturalism is the suspension of belief in divine causation, and by entailment, of the belief that events that violate the laws of nature sometimes occur and that while epistemological humility does not, however, require the suspension of knowledge of how the world works, (that is, of the laws of nature) on the one hand, methodological naturalism, therefore, requires us to reject the literal truth of reports in ancient texts of events that we know to be physically impossible, regardless of whether a text attributes such events to divine causality on the other hand. To Miller, reports about the deeds of Jesus are not exempt from this methodological restriction. Methodological naturalism, and the epistemological humility subsume, therefore, requires that historians deny, for example, that the historical Jesus (the human Jesus as reconstructed by critical historiography) literally walked on water. Since epistemological humility does not require 
the suspension of knowledge about how the world works, but only of belief in divine causation, it therefore does not require that one hold open the possibility that the historical Jesus walked on water, since that possibility is incompatible with naturalism (both ontological and methodological). Robert J. Miller is a lecturer in Juniata College, Huntingdon, Pennsylvania, USA. One question that can be raised here is: can the historical critical method or science be used to verify the reality of biblical miracles? Did those miracles happen? The gospel writers are saying yes. Although, the gospel can be subject to some sought of critical analysis, these disciples should not be doubted since they actually witnessed the events they wrote about. Although, there are some inconsistencies in some of the accounts of the evangelist as a result of human errors, that cannot make their presentation invalid. This paper shall adopt the Ukpong and other methods of posing the historical Jesus questions. Within their framework, the historical Jesus question can be posed from both the historical method and contextual paradigms.

\section{Posing the Historical Jesus Question}

The Historical Jesus research poses a lot of questions to the critical mind and even the scholars alike. These questions force out some critical answers. This is why one can say that Biblical exegesis has to do with posing question to the text and getting answers from the text. Attempting this within western biblical scholarship, Ukpong (2008) identifies four general ways of posing and answering the historical Jesus question, thus:

One way is that of reconstructing the historical image of Jesus in the form of a biography from the New Testament material. The focus is on Jesus within the society at large and not only within the church. This is the way the question was posed in the $19^{\text {th }}$ century question of the historical Jesus, generally referred to as the "first quest". Its main weakness is that it presumes that what we encounter in the New Testament is not Jesus as he was in himself, whereas it is Jesus as understood by those 
who believed in him. The gospels are therefore not a good source for reconstructing the historical figure of Jesus. Hence, the "first quest" was later considered futile, and was abandoned. The "new quest" also called the "second quest", dominated most of the $20^{\text {th }}$ century. Initiated by Ernst Kasemann, this approach poses the question in terms of what, in the New Testament, can be attributed to the historical person of Jesus with some amount of certainty. It thus focuses "primarily on the question of continuity (or not) between the historical Jesus and the proclaimed Christ of the church." It goes about its task by establishing certain criteria for isolating Gospel materials into those that can, and those that cannot, be attributed to the historical Jesus. The emphasis is mainly on the saying of Jesus. The work of "The Jesus Seminar" of Westar Institute is a good example of this. This approach still goes on today. For the "third quest" of late $20^{\text {th }}$ century, the question is that of understanding Jesus as a human person among his contemporaries. It therefore seeks to reconstruct the historical figure of the man Jesus against the background of the history, culture and society of first century Palestine and the Roman Empire. It employs a complex interdisciplinary methodology that draws upon history, archaeology, sociology, cultural anthropology, and literary studies. In relation to the approaches of African scholars, four points may quickly be noted here. One is that all the above approaches focus on the person of Jesus and his actions, and seek to understand Jesus from within his historical past. However, it is not expected to recover the Jesus that walked the streets of Nazareth in first century Palestine exactly as he was, but his person as far as historical tools of scholarship can reveal him. On the other hand, 
African hermeneutical focusing on the existential significance of Jesus in a way that is not purely historical but also theological. Second, all the above approaches are interested only in the Jesus of Jesus of first century Palestine. In other words, the sole context on which they focus is Jesus' historical context. However, in consonance with the general goal of African biblical scholarship of making the Jesus that is behind the biblical text "alive and available" to ordinary African Christians, African scholars focus both on the historical context of Jesus and the contemporary social cultural context of Africa. Third, it is well accepted in New Testament scholarship today that exegetical conclusions are directly related to the assumptions of the exegete. The above western approaches seem to be based on the assumption that there is an unbridgeable gulf between the historical Jesus and the Christ of the Christian faith. However, while African exegetes accept that there is a gulf, they do not see it as unbridgeable. Fourth, and perhaps most important in terms of shaping the research on the historical Jesus, the western approaches seek "to reconstruct a purely historical conception of the life of Jesus free from the 'simple-minded supernaturalism' of the first century." African scholars view it from historical, natural and supernatural dimensions. A Jesus conceived in purely historical terms is considered incomplete.

Another way of posing the question is by elaborating on the Reimarus-Schweizer's quest. The historical Jesus quest was elaborated by Schweizer to pose the question of the historicity and personality of Jesus of Nazareth. The aim of Shweizer according to Gathercole (2000:263) was to destroy the portrait of the Jesus of liberal German theology which tried to make him a nineteenthcentury figure who could be a relevant example, and to reinstate the 
real historical Jesus, who for Schweitzer was an apocalyptic prophet who attempted (heroically, but unsuccessfully) to bring an end to world history. Gathercole agued further that Schweitzer structured the book written by him around Reimarus, Strauss, Weiss and himself, as they aim to show the impossibility of maintaining Jesus' own dogmatic construction of eschatology in the modern era. Within this argument, the question that is being asked by the African Christian and scholars alike remains clear. The question is: just as Schweizer tried to differentiate the Jesus of the church faith from his constructed historical Jesus in Germany, can this Jesus of faith as presented by the Bible be separated from the Jesus of history in African Christianity? Does Schweitzer's postulation on Jesus destroy faith or build faith in Africa and elsewhere? To African Christianity, Jesus of Nazareth is the same Jesus described or spoken about by the bible and as such, any attempt to reduce that Jesus to a mere historical figure who lived within time and space is to pose a serious problem to Christian faith. Bird (2004) opined that following Schweitzer's devastating critique, "the intervening years between the First and Second World War saw a marked decrease in interest in historical Jesus study (though interest did not completely wane, especially amongst English-speaking scholars)." Bird explained that this is partly attributable to the rise of Karl Barth's neo-orthodox theology and Rudolf Bultmann's demythologisation which made the Jesus of history either irrelevant or irretrievable, although both scholars strenuously denied this; it seemed the logical implication of their work. In Ernst Käsemann's lecture of 1953 at the University of Marburg on 'The Problem of the Historical Jesus,' he contended that Easter did not totally eradicate the continuity between Jesus and the early church (Käsemann, 1964). The primitive church never lost its interest in the life history of Jesus as being properly basic for faith. This led to a new impetus in the Jesus research which has subsequently become known as the 'New Quest' for the historical Jesus (Robinson, 1959). Its notable proponents have included James Robinson, Günther Bornkamm, Norman Perrin, Eduard Schweizer, Ernst Fuchs, Eduard Schillebeeckx. The Jesus Seminar arguably belongs to this camp. The New Questers have felt a little more 
Ottuh: Posing the historical Jesus question...

confident about outlining a life of Jesus by use of form critical tools (Bird).

Moreover, Bird, citing Neil and Wright (1988); Wright (1992) observed that in contrast to the skepticism of the 'First' and 'New Quest,' a recent paradigm shift has occurred in historical Jesus studies in the last twenty years that has subsequently been called the 'Third Quest for the Historical Jesus.' Also, Bird in agreement with Reumann (1989); Allison Jr (1996); Telford (1994); Theissen and Merz (1998); Perrin (1967) says that what distinguished the Third Quest from the New Quest are three main things:

i. An emphasis on the Jewish nature of Jesus and early Christianity. Whereas scholars in the Bultmannian era attempted to understand Jesus in the context of the theology of the early church, scholars are now studying Jesus within the context of first-century Judaism. ii. A general consensus has emerged that Jesus' message was predominantly eschatological. The 'kingdom of God' to which much of Jesus' ministry was directed to does not refer to an egalitarian utopia but must be understood via the matrix of Jewish apocalyptic expectation.

iii. A greater degree of optimism concerning the historical reliability of traditions concerning Jesus in the canonical Gospels.

Another way of posing the Jesus question is by approaching it from the angle of identity, time and place. Also Schweitzer (2004), quoting Williams (1987: 235-238), asserted that one of the church's perennial tasks, as it seeks to be responsible in its witness, is to ask about its own identity and calling in the time and place where it finds itself. In order to do this, the church must frequently ask the same or similar questions over and over again in each new age. In Don Schweizer's opinion the quest for the historical Jesus is a part of this and it continues because the church continues, and always 
needs to seek clarity about the person of Jesus who it claims to follow, in order to have clarity about its' own positions in the conflicts of its day, recognizing the differences between this and Jesus' time. Charlesworth (2011) suggests that the historical Jesus question can be posed by asking; who was Jesus? What was his purpose? What was his essential message? What reliable historical information do we have concerning him? Did he attempt to establish a new religion that would be different from the Judaism he knew? Why was he crucified? Did the Palestinian Jesus Movement not end with his death, as reflected in the dashed hopes of Cleopas: "We had hoped that he is (or was) the one about to redeem Israel" (Luke 24:21)? Moreover, Charlesworth added that we need to continue to explore such questions as these: "Why was He crucified? How and in what ways was Jesus influenced by contemporary Jewish ideas? How reliably do the evangelists report pre-70 Jewish thinking? Who was the first Christian?" To him, such questions have ushered in a new phase of Jesus research.

\section{Goal of African Biblical Scholarship}

Is there any difference between the goal of African biblical scholarship and that of the west? Although this study is not intended for this argument, at least we can see that there are some differences. One of such differences is that while the western scholars intend to satisfy scholars (Holmén and Porter, 2011: xvi), those of Africa intend to satisfy both scholars and the ordinary readers of the Bible. It is on this basis that Ukpong (2008) noted that African scholars have realized that the mode of reading the Bible they learned in Europe and the USA cannot be pressed into answering African faith questions with satisfaction. For, answers to questions can only be satisfactory when they are on the same "frequency" with the questions, that is, when they share the perspectives of the questioners. Hence, over the years, they have developed their own distinctive goal and interest in biblical research, and adopted various non-western approaches to reading the Bible among which are those that are informed by the ordinary people's approach to the Bible. Moreover, Ukpong (2008) gives the following goals of African biblical scholarship: 


\section{Availability of the Bible to Ordinary Readers}

The basic goal of African biblical scholarship is to make the bible available to the ordinary African Christians as a means of supporting and strengthening the Christian faith. It is concerned to answer faith questions of the ordinary African Christians - questions that are sometimes very different from those of Europe and the USA. The end in view is the empowerment of the ordinary people in their life in Christ. Thus, the ordinary Christians take precedence over academics as the primary dialogue partners of African scholars: it is to the ordinary Christians that African scholars consider themselves in the first accountable. Their scholarship is not detached from faith.

Though this basic goal has not been fully attained, there is no doubt about it as the end in view. Assessing the attainment of this goal in Ghana, Ukpong, citing Obeng (2001:40), observes that "Biblical scholarship has not made an impact on the thinking of the people in Ghana. It has remained an academic exercise among a few scholars in the public universities.... Majority of the populace have not been touched by their interpretations." Among Obeng's recommendations for the future is that "there should be collaborative research between biblical scholars in the public universities and theological colleges," and that research "should be practically oriented to address issues of poverty, hunger, disease, governance and corruption." To Obeng, repeating the interpretations found in the West is not "in the interest of Ghanaians," and for that matter, Africans in general. Ukpong concludes that Obeng's observations resonate the thinking of most African scholars because in the first place, Obeng presupposes that biblical scholarship should have an impact on the populace. This suggests a wide spectrum of interest among African scholars in the sense that they seek to reject the alienation biblical scholarship from the common people because it exists for their benefit. Moreover, clearly, alienation takes place where there is repetition of the modes of readings found in the West where biblical scholarship is not concerned to address the issues that arise from African contexts.

Many reasons have been adduced for the concern of African scholars to have biblical scholarship impact the society. These include the fact that most African biblical scholars are people with 
pastoral responsibilities. African culture has not experienced the Enlightenment like the west. African worldview is similar to that of the Bible, etc. While all this may be true, it would seem to me that the circumstance in which the Bible came into Africa has a fundamental role to play. The initial contact of the Bible with African people and society south of the Sahara encouraged more of the alienation of the people from the Bible than acceptance of it. The Bible was deeply implicated in the western colonialism-imperialism project in Africa. In the name of biblical religion, African culture and religion, the fabric of the people's life, were condemned without a hearing as incompatible with Christianity. One would therefore have expected African Christians to reject the Bible along with those who brought it to them. However, rather than reject the Bible, African Christians appropriated it in their own way and subverted the alienating usage to which it was put. This was expressed, in a major way, in the establishment of African Instituted churches (commonly called African Independent Churches) that began to flourish in the 19th century in different parts of Africa. In these churches, the Bible was seen differently with African "eyes" and appropriated for the building of the Christian faith. This seems to prove the deconstructionist position that any text, including the Bible, "can be read in contrary ways, each of which denies the primacy of the other". African churches were captivated by the Bible and its message. They had discovered in the Bible a different God and Jesus from what, in many respects, the missionaries were presenting to them. In a large measure, the contemporary progress of Christianity in this region, owes its success to this phenomenon.

\section{Uncritical Reading to Critical Reading of the Bible}

Ukpong, citing Pette (1995:102-103), argued that all critical readings of the bible start from uncritical reading: they are ordinary readings raised to critical consciousness. This depicts the fact that academic readings of the Bible in Africa today, excluding those that follow the western pattern, follow on the trials of the early uncritical initiative of the African Instituted church movement. The missionaries had used the Bible to condemn African culture and thus alienate the people from Christianity. However, in their readings of the bible 
both the African Instituted churches, and African scholars have discovered existential similarities and affinity between African culture and biblical religion. Although African scholars use the historical critical method in reading the bible, they are also conscious of the African culture especially those cultures that resonate that of the Bible. This made them to put the contemporary context of interpretation into consideration. The contemporary context could be placed before or after the biblical context to construct a resonance. This type falls into comparative and evaluative models of African methodology of biblical interpretation.

\section{Faith Building}

To Ukpong, African scholars read the bible to build up the Christian faith. In this same line of thought, Ottuh (2014) opined that irrespective of scholarly debates, on Jesus, an African Christian cannot afford to acadamize faith to the detriment of personal salvation experience. Therefore, the Christ we preach in Africa, like that of the missionary, is the Christ who was sent by God from above to earth to save mankind from sin and eternal damnation. The faith in this Christ requires repentance, confession of sins and constant profession of faith on this same Christ as the one who resurrected from the dead as Lord. Ottuh further explained that Christian experience in the Christian understanding is to become born again (John 3:1-6) and remaining in the didache (teachings) of Jesus Christ. Being a Christian starts at the point where one received and put his faith in Christ as his personal Lord and saviour. Paul had this experience while on his way to Damascus to persecute the Christians of his time (Acts 9) and never remained the same again. Paul also taught that becoming a Christian is not on the basis of cultural affinity but on the basis of faith in Christ the saviour in one's cultural milieu. While the issue of faith for salvation is universal, the method of preaching the faith to all nations of various cultural backgrounds for them to understand it varies from culture to culture. This faith for salvation will be truncated if the bible, for instance, is mythologized. 


\section{Impacting on Society}

To Ukpong, the Bible is seen as an important tool in rooting Christianity in the community. Another important consideration regarding the concern to have the Bible impact society is that African scholars see the Bible as a sacred classic, that is, a religious book with spiritual and moral authority for Christian living as well as an ancient literary document which worth attention beyond its time. As a literary text, it is a cultural product that can be investigated with the tools of secular literary practice. Ukpong, citing Stuhlmacher (1979:86-88), said that the tools of biblical criticism should be used simply as tools and should not be allowed to become an end in themselves or a master. Many African scholars do precisely that: they use critical tools to aid interpretation of the Bible in the African context. As an ancient document, it is appropriately read with the tools of secular history. However, the interest here is not recovering the intention of the author but discovering how the text functioned in its particular historical context. Besides, the aim is not merely to discover the historical meaning of the text but also to make it come alive in the contemporary social historical context. African scholars do not treat the Bible as an artifact of mere historical or literary interest, but see it as meaningful and relevant for the present context. As a sacred text, the Bible is seen as God's liberating word that has significance for humanity today and as such, it needs to be actualized in the human community. Interpreting it thus means unleashing the liberating message of God to be experienced as Good News in the concrete human society. Ukpong's point here depicts the fact that African scholarship will be useless if it does not contribute to human transformation and societal development.

\section{Integration}

Ukpong also presented here, a holistic and pragmatic nature of African epistemology. Ukpong, citing Anyanwu (1981:78), pointed to the African's integrative way of perceiving reality in which rationalism gives way to aesthetics and synthesis. According to him, "the African epistemology is dominated by the philosophy of integration with regard to what constitutes trustworthy knowledge 
and reality." For Africans, for example, truth is not an abstract entity, but rather something to be experienced in the concrete. Hence, the message of the Bible needs to be related to the present context. African biblical scholars see any approach in biblical studies as a tool employed in the service of a task to attain a certain goal. They are also aware that every such tool is developed within certain contexts and for certain purposes albeit subconsciously. They therefore view western exegetical tools with "hermeneutic suspicion", that is, they see them as serving western goals and interests that may not correspond with theirs. They therefore use these tools not slavishly but critically (Ukpong 2008, citing LeMarquand 1997:164; Ukpong, 1999:2-5). LeMarquand (2000) also opined that the interface between popular and academic readings is an important motif in African exegesis. Popular readings and the use of the Bible by ordinary people is taken seriously. African scholars are not unafraid to criticize some popular uses of the Bible but in contrast to the disdain for popular readings one sometimes discovers among western scholars, African scholars are generally only willing to criticize the faithful with a good deal of respect and understanding.

\section{Bridging Gaps (Striking a Balance)}

In addition to the Goals of African Biblical scholarship given by Ukpong above, one of the goals of African Biblical scholarship is to bridge the gap created by cultural distances. This cultural distance is either between African cultural and the biblical milieus or between Western cultural and African Cultural setting. This distance was created by western scholars in the sense that they refuse to see the nearness of African culture to the Bible especially the Old Testament. Waweru (2011:7-6) asserts that Africans accepted the gospel so easily when the missionaries came to Africa to preach it and that as a result, the Africans were made to abandon their culture.

The missionaries' methods could have created some vacuums since they have the orientation of the western method. Some African scholars have also shown that Africans accepted the bible so easily probably because there are many similarities between African cultures and biblical culture. For instance, LeMarquand agrees with Dickson (1973) that the worldview of African peoples is 
close to the Old Testament, or that Africans feel more at home with the Old Testament than with the New. However, African Christians do not take for granted the salvation message that is centered on Jesus Christ in the New Testament. If the culture of Old Testament is closer to African culture, how do we justify the claim that there is a distance between biblical milieu and that of Africa. Although, scholars like LeMarquand and Dickson have agreed that the Old Testament culture is nearer to that of Africa, we cannot deny the gap created by western reconstructionists who sidelined Africa despite the role of Africa in Biblical history. This is probably one of the muse that led Adamo (1998); Habtu (2001) ; Ntre (2001) into the African in the Bible research. Their research showed that Africans have played a major role in biblical history but has not been properly placed by western scholars. One of the areas where the gap is created by the western missionaries is in the area of marriage ceremony. The type of marriage ceremony prescribed by the white man was the importation of their culture. For example, both African and Hebrew cultures accept the payment of dowry on a woman before such woman can be regarded as a wife. In Nigeria, for instance, even when one goes to church to wed a woman, the African culture in Nigeria does accept such woman as a wife to the man until, the dowry is culturally paid (Waweru, 2011:170-185). This is why we are doing three wedding ceremonies today in Nigeria among Christians.

In a nut shell, African scholars are being challenged by what they feel is an alienation of Africa from biblical experience. Hence, their contribution tends to fill the gap so created by western scholars and even the biblical text. This is termed contextualization in African biblical scholarship.

\section{Euangelion}

Another goal of African Biblical scholarship, apart from the ones pointed out by Ukpong, is euangelion. The term euangelion (gospel) is a Greek term referring to the preaching of the Good News. Here, Good News means the Gospel or the Word of God. Many of the scholars in Africa are pastors (priests) who were trained in church oriented theological institutions with the consciousness of winning 
souls for Christ. This act of winning souls is called evangelism. They were even told that their basis of training is evangelism and as such, their scholarship also intends to make the reader to be transformed. For example, in the Urhobo language in Delta State of Nigeria, the pastor is very familiar with the term eyerhesiri meaning good news. Any scholasticism that discourages faith will be rejected with all consciousness.

\section{The Evidence of the Jesus of Faith in the Jesus of History within African Context}

Here, we intend to show how the Jesus of faith is truly evidenced in the Jesus of History within African Context. African biblical scholars have done a lot of works as earlier pointed out. From the South African experience, Botha (2009) revealed that South African biblical scholars have published widely on various topics, and have gained international repute on many terrains, such as modern linguistic approaches to the Greek of the New Testament, discourse analysis (Holgate \& Starr 2006:48), study of the Gospel of John, and exegesis of Pauline Letters. The historical Jesus, however, has never been of much interest among South African scholars, despite the efforts of a few talented researchers since the last quarter of the twentieth century. The evidence of Jesus of faith in African historical Jesus research can be multidimensional. Here a few dimensions will be considered.

First, the dimension of miracles and the voice of Jesus in the account of the evangelist, African scholars in recent times have attempted to view the historical Jesus research from the perspective of the miracles and the voice of Jesus within the text. The question in contention is to identify the voice and miracles of Jesus within the text. The question is: are those sayings of Jesus actually His sayings? Are those miracles of Jesus in the Gospels actually performed by Him as reported by the evangelists? Is the Jesus of Nazareth the one who said those words and performed those miracles in the New Testament? All of these questions were attempted. For instance, Evans (1988) observed that though the historical Jesus research in the last three decades has produced a great deal of divergence of results, one is able to discern several important areas of progress especially in the area of a renewed 
appreciation of the Judaic character of Jesus, his mission, and his world. New source material and more nuanced, contextual methodology have sharpened Jesus' profile as a Galilean Jew, standing in the tradition of Israel's redemption and restoration. Moreover, in Nolan's (1976:21-36) view, the miracles and the ipssisima vos yesu (the voice of Jesus) in the account of the evangelist are veritable evidence for arguments in the Historical Jesus question in Africa. For instance, the healing stories are situated in a traditional setting and reference to the ancient worldview is made. To Nolan, Jesus' compassion and trust in God enabled these powerful events, and Jesus' aim was to awaken the same compassion and the same faith in the people around him. Although he avoids a supernaturalistic interpretation of Jesus, Nolan understands Jesus to have been quite unique, 'a much underrated man, a man of extraordinary independence, immense courage and unparalleled authenticity, a man whose insight defies explanation' (Nolan 1976:117). To the scholars of the $18-19^{\text {th }}$ century like Raimarus and Schweitzer, the presentation of Jesus' miracle and voice are figment of imagination (Schweitzer, 1906). Their conclusion was based on scientific study of the Bible resulting from the aufklärung (enlightenment). One weakness of this method is the fact that biblical miracles cannot be verified by scientific means even though scientific apparatus can be useful in the reconstruction of the historical Jesus research. This presents a conflict between faith and reasoning in the sense that an African Christian does not need a scientific proof of the bible before believing in Jesus Christ as presented by the evangelist. Here without any scientific theory or verifications, the historical Jesus is being regarded from biblical presentation as one individual who is both historical and Christian faith figure. He was an Historical figure because He was the son of man who lived among men within time and space (John 1:14) and He was a figure of Christian faith in Jewish and contemporary milieus because His sayings and deeds as presented by himself and the evangelists are believed to be correct and true even though there were some nuances in the accounts.

Second, the dimension of historicity of the account of the evangelist, Nolan acknowledges that history is a reconstruction, that 
'it is the truth of the past in the light of the present' and that to 'imagine that one can have historical objectivity without a perspective is an illusion' (Nolan 1976:4), but he shows no concern with the problem of how to deal with subjectivity. Despite many claims throughout the book, it is not critical historiography. He alleges 'the consistent use of strict historical criticism and methods of research', but the crucial, unresolved problem becomes evident in the second part of that sentence: 'our interest is not the academic pursuit of history for the sake of history' (Nolan 1976:1). Nolan's concern to overcome the divide between (academic) understanding and (practical) relevance becomes an affirmation of that dualism. At the really crucial stages of the presentation, critical analysis and historical probing are left behind and reductionist affirmations are employed (Botha 2009, citing Nolan 1976). Among African scholars, the most pressing challenge at hand is further clarification of the interaction of theology and critical history, especially in the light of the church life and belief. This is why scholars like Botha (2005), Van Aarde (1999; 2004) and Craffert (2006; 2007) emphasize that a deeper understanding of reality, with a more holistic and complexifying approach to controversies, is unavoidable (Botha, 2009). How does African Scholars and Christians approach the scientific historicity of the Jesus of the New Testament? While the African scholars still rely on the Western scholars in addition to the narratives of the evangelist to scientifically prove the historicity of the figure of Jesus in the New Testament, the African Christian simply relies on the narratives of the New Testament about Jesus. One task which an African biblical scholar who intends to do a research for the church in Africa will face is, the dynamism and creativism of striking a balance between critical scholasticism and faith based construction of the figure of Jesus. As it stands now, some African scholars like Adamo (1998); Habtu (2001); Ntre (2001) and the likes of them have reconstructed biblical history in order to trace the relevance of Africa in Biblical history. They have shown that Africa has a firsthand witness in the history of biblical figures, be they human, place or movement. At least there were some interaction between Jesus and Africa. One of such interactions was His stay in Egypt when there was a serious threat to his life after His birth (Matthew 2:1-15). Another interaction was the 
participation in the carrying of the Cross with Jesus by Simon of Cyrene when he was tired (Mark 15:21; cf. Luke 23:26). These stories authenticate the historical figure of Jesus Christ as the son of man and saviour of the world in African Christianity.

Third, the dimension of existentialism in the presentation of the evangelist, The Gospel of John 1:1-14 presented to us the logos (the Word) as incarnated in the person of Jesus. That Jesus existed on planet earth is not in dispute but the question has been that of an identity between biblically and scientifically reconstructed history on the person and ministry or deeds of Jesus. Wells (2004), van Voorst (2000) agree that biblical scholars are convinced that Jesus existed. While they disagree on several matters of central importance to the understanding of Jesus and early Christianity, this is a crucial point of considerable agreement. The quest for the historical Jesus is not a quest for his existence as such, but for the more precise contours of his person and career. In this regard, Byrskog (2011) raised some questions as follows: how do we know that he in fact existed? In what sense can we speak of his historicity? How do we approach history? How do we employ the ancient documents in order to reconstruct the historical Jesus? What sources do we have and what is our attitude to them? Is it really possible to move out of our own context and reach back to the bare history via documents and traditions? These type of questions have recently come to the fore in historical Jesus research and promise a more hermeneutically informed sensitivity to the conviction that Jesus in fact existed. To Byrskog, the claim that someone existed in history is based on what is perceived as the scientific enterprise of historical reconstruction. Snodgrass (2005) argues that existentialism is valid within human linguistic understanding especially as it relates to Jesus' parables in the New Testament. One question that can be raised concerning Jesus' parables in the New Testament is to find out whether the parables were fictions or real incidents within time and space. Another issue is the African understanding about existentialism. The African understanding of the living dead and spirits are ideological and philosophical. The African person is not ignorant of existence in his physical and metaphysical environment. However, how can the African scholar prove that Jesus existed? If such scholar must 
contribute, he needs to resort to the historical critical method and materials presented by western scholars because they have been involved in this enterprise for long.

Fourth, the dimension of the ordinary reader, this dimension puts those who do not have the technical know how of biblical studies into consideration. The ordinary reader in this context could be a well schooled person but such person did not do religious studies or biblical studies. They study the bible but not with the historical critical method or critical apparatus of the bible. They do not understand deep scholarly approach but at least they understand the bible in its face value. An African scholar who is considering this type of audience in the Historical Jesus study will rely more on bible stories so as to strike a balance between faith and systematic study of the bible. This will inform faith, not fanaticism. This does not stop the scholar from doing a critical study but it has to be done across chains of level. Here the ordinary readers of the Bible are familiar with church dogma and as such church authority supersedes critical approach in the study about Jesus. One weakness in this type of reading is the unwillingness of the ordinary bible reader to go through the rigour of critical biblical study. However, Akper (2005) is of the view that the voices of the "ordinary readers" in the collaborative reading need to be clearly evident, so that it does not seem as though the socially engaged biblical scholar is simply reading through the "ordinary readers." This is a new trend in African Biblical scholarship and, of course, it is advocating that the ordinary reader should also be put into consideration when doing a critical study of the bible (Okure, 1993:77). The ordinary reader believes in the story of the bible the way it is presented. Another problem with the ordinary reader at this point is a tendency to spiritual everything in the bible story. Such type of reading is equally dangerous because such reader could as well misinterpret the bible. A story was told of a man in Delta State of Nigeria who cut off his penis when he read:

But I say to you that everyone who looks at a woman lustfully has already committed adultery with her in his heart. If your right eye causes you to 
sin, pluck it out and throw it away; it is better that you lose one of your members than that your whole body be thrown into hell. And if your right hand causes you to sin, cut it off and throw it away; it is better that you lose one of your members than that your whole body go into hell (Matthew 5:28-30 RSV, 1952).

This reader simply misunderstood the bible passage. This is why it is important to do a critical study of the bible with the ordinary reader of the bible so as to enhance the intellectual and faith development of the ordinary reader. This is an aspect that African scholars have put into consideration to help liberate and broaden the intellectual horizon of the ordinary reader so as to appreciate the reality of the historical background behind the bible text. While the miracles of the bible cannot be verified by scientific apparatus, happenings around biblical times can be subjected to critical thinking and postulations. By so doing, critical reading will give insight for plausible postulations.

Fifth, the dimension of inculturation in the presentation of the evangelist, Inculturation hermeneutics is another new dimension of African Biblical studies. This new venture belongs to the contextual approach of biblical interpretation in Africa. The 2004 Annual Conference of the Nigerian Association for Biblical Studies (NABIS) was held at Lagos State University, Ojo, Nigeria, from 9 to 13 July 2004. The theme of the conference was Decolonizing Biblical Studies in Africa. More than one hundred participants from universities and seminaries all over Nigeria, as well as some international scholars, attended the conference. The following commissioned papers were presented: Dr J.A. Oladunjoye: "Decolonizing Biblical Studies", Prof J.S. Ukpong (Catholic University of West Africa, Port Harcourt): "Inculturation as Decolonization of Biblical Studies", Prof S. Abogunrin (University of Ibadan): "Decolonizing New Testament Interpretation in Africa", Prof D.T. Adamo (Delta State University): "What is African Biblical Studies?", Prof G.O. West (University of KwaZulu-Natal, Pietermaritzburg): "Decolonizing South African Biblical Studies 
Ottuh: Posing the historical Jesus question...

Interpretation: The task before and after liberation", Dr D.O. Agintunde: "Decolonizing Biblical Studies in Nigeria: Women Perspective", Prof Chris Manus, (Obafemi Awolowo University) "Decolonizing New Testament Interpretation in Nigeria", Prof. Willem Boshoff (University of South Africa, Pretoria): "Decolonizing Biblical Studies in South Africa" (http://www.mhs.no/aotp?20). All these African scholars have done much on the subject of contextualization of African biblical studies. Here, both the cultural and secular aspects of the biblical milieu are being presented as interrelated. Hence, the Historical Jesus can be seen in African scholarship as a man of biblical as well as societal figure who spoke Hebrew and Aramaic languages. This Jesus addressed people, ate food and dressed in the attire of his culture. This showed that the Jesus being presented by the evangelist as figure of Christian faith is also a figure of historical study. If $\mathrm{He}$ spoke Hebrew and Aramaic, who did He speak with? If he ate which type of food did He eat? If He wore clothes which type of clothes did $\mathrm{He}$ wear? If $\mathrm{He}$ interacted with people, which people did He interact with? An attempt to answer these questions in African biblical scholarship will give useful insight into historical figure of Jesus.

Sixth, the dimension of dialogical and praxeological appropriation in the presentation of the evangelist, this aspect poses the question: who did Jesus interact with and how was his action or behaviour like? He interacted with people like the disciples, the Jewish society, the intellectuals, Roman officials and reacted to issues of society. Recent discoveries by archaeological findings in the Qumran community near the Dead Sea in January 1947, has shown that Jesus lived among the Jews and did good to people especially the oppressed. He preached the Kingdom of God like John the Baptist and was followed by multitudes as a result of His humanitarian works and miracles (Varner, 1997). In the opinion of West (2008) the three key elements of African biblical interpretation are the biblical text, the African context, and the act of appropriation through which they are linked. The biblical text and African context do not on their own participate in a conversation. For dialogue to take place between text and context a real flesh and blood African reader is required! This reader moves constantly back and forth 
between the biblical and African context, bringing them together in an ongoing conversation which we call appropriation. How the reader moves between text and context is determined by a range of factors, including their ideo-theological orientation, their ecclesiotheological missionary heritage, their engagement with ordinary readers of the Bible in the church and community, and the important issues that require attention in the African context. To Ukpong (2000:24) one of the important aspects of biblical scholarship in Africa is the actualization of the theological meaning of the text in today's context so as to forge integration between faith and life, and engender commitment to personal and societal transformation. What connects text and context, then, is a reader who activates a form of dialogical appropriation that has a theological and a praxeological dimension. This dimension is a challenge that calls on African scholars to have interaction with the presentation of the evangelist about Jesus to find out about the people Jesus interacted with and His behaviour within his community where he lived.

\section{Conclusion}

Contextualization of the historical Jesus question is by no means a small task in scholarship. Using Ukpong and other models in this subject matter, this paper has shown that the historical Jesus question can be framed contextually. Ukpong, Okure and other similar scholars in their shoes are of this opinion. Within this context, while the first quest sought to reconstruct the biography of Jesus from the New Testament materials in the $19^{\text {th }}$ century and separated the Jesus of the New Testament from the Jesus of history, the second quest in the $20^{\text {th }}$ century poses the question in terms of what, in the New Testament, can be attributed to the historical person of Jesus with some amount of certainty. On the other hand, the third quest in the late $20^{\text {th }}$ century, poses the question of understanding Jesus as a human person among his contemporaries and sought to reconstruct the historical figure of the man Jesus against the background of the history, culture and society of first century Palestine and the Roman Empire. 
Moreover, the study has also shown that the goal of African Biblical scholarship is different from that of the West as that of Africa include: making the bible available for the ordinary readers; uncritical reading to critical reading of the Bible, faith building; impacting on society; integration; bridging gaps (striking a balance); and euaggelion. African scholars do this to make biblical scholarship congenial with the church in Africa. Although African scholarship is done to satisfy very high profile scholars in the globe, such scholarship also bears in mind that any scholarship done to discourage the faith of the African Christian will birth a serious ecclesiological crisis.

One recommendation we must not fail to bring to table here is the need to allow African scholars to develop and pose the Historical Jesus question and answer such question from an African Christian perspective. This should also be respected among committees of international scholars. It is worthy of note here, that this work does not in any way suggest fanaticism or bigotism or present a polemic against western scholarship but it is an attempt to, at least, blend the western method with that of Africa so as to make Historical Jesus research to be relevant to both the academia and the church in Africa.

*John Arierhi Ottuh, Nehemiah Bible College, Okwokoko E-mail: wibachef90@yahoo.com, Wibachef90@gmail.com 


\section{References}

Adamo, D.T. (1998). Africa and Africans in the Old Testament. San Francisco, London: Christian University Press, 364pp.

Allison Jr., Dale C. (1996). The Contemporary Quest for the Historical Jesus. IBS 18: 174-180.

Akper, Godwin I. (2005). The role of the 'ordinary reader' in Gerald O. West's hermeneutics. Scriptura: International Journal of Bible, Religion and Theology in Southern Africa 88: 1-13.

Botha, Pieter J.J. (2005). Theology, rationality and truth-claims: Metatheoretical reflections on self-deception. Religion and Theology 12(2): 97-128.

Botha, Pieter.J.J.(2009). Historical Jesus research and relevance in South Africa', HTS Teologiese Studies/Theological Studies 65(1): 154-165. DOI:10.4102/hts.v65i1.154.

Burer, Michael H. (2004). A Survey of Historical Jesus Studies: From Reimarus to Wright. https://bible.org/article/surveyhistorical-jesus-studies-reimarus-wright\#P12_903.Retrieved

March 23, 2015.

Byrskog, Samuel. (2011). The Historicity of Jesus How Do We Know That Jesus Existed? In: Tom Holmén and Stanley E. Porter (eds) Handbook for the Study of the Historical Jesus. Leiden: Brill, 2183-2212

Charlesworth, James H. (2011). The Historical Jesus: How to Ask

Questions and Remain Inquisitive. In: Holmén, Tom and Porter, Stanley E. (eds) A Handbook on Jesus Historical Research. Leiden: Brill, 91-128.

Craffert, P.F. (2006). Multiple Realities and Historiography: Rethinking Historical Jesus Research. In: C. Breytenbrach, J.C. Thom and J. Punt (eds.) The New Testament Interpreted: Essays in honour of Bernard C Lategan. Brill, Leiden, 87-116.

Craffert, P.F.(2007). New Testament Studies-preventing or Promoting a Humane Society? Religion and

Theology 14: 161-205.

Dickson, Kwesi. (1973). The Old Testament and African Theology. Ghana Bulletin of Theology 4 (4): 3-41.

Elenga, Yvon C. (2002). African Christologies: Naming Jesus. Theology Digest 49 (3): 229-232. 
Ottuh: Posing the historical Jesus question...

Evans, C. A. (1988). The Historical Jesus and Christian Faith: A Critical Assessment of a Scholarly Problem. Christian Scholar's Review 18 (1): 48-63.

Gathercole, S.J. (2000). The Critical and Dogmatic Agenda of Albert Schweitzer's the Quest of the Historical Jesus. Tyndale Bulletin 51 (2): 261-283.

Habtu, T.(2001). The Images of Egypt in the Old Testament: Reflections on African Hermeneutics. In: Getui, M.N.; Holtner, K. and Zinkuratire, V.(eds.) Interpreting the Old Testament in Africa. Nairobi: Acton Publishers, 55-64.

Haight, R. (1999). Jesus Symbol of God. Maryknoll, New York: Orbis Books.

Holmén, Tom and Porter, Stanley E. (2011). Introduction: The Handbook for the Study of the Historical Jesus in Perspective. In: Holmén, Tom and Porter, Stanley E. (eds) A Handbook on Jesus Historical Research. Leiden: Brill, xvxxi.

Käsemann, Ernst. (1964). The Problem of the Historical Jesus.

Essays on New Testament Themes, trans. W.J. Montague.

London: SCM.

Keener, Craig S. (2011). Assumptions in Historical-Jesus Research: Using Ancient Biographies and Disciples' Traditioning as a Control. Journal for the Study of the Historical Jesus 9 (1): 26-58.

LeMarquand, G. (1997). African New Testament Scholarship. In:

William E. Arnal and Michael Desjardins (eds.) Whose Historical Jesus? Studies in Christianity and Judaism No.7.

Waterloo: Wilfred Laurier University Press.

LeMarquand, G. (2000). New Testament Exegesis in (Modern) Africa. In: Dube, M.W. and West, G.O. (eds) The Bible in Africa: transactions, trajectories, and Trends. Boston, Mass: Brill, 72-102.

Loba-Mkole, Jean-Claude. (2005). Rise of Intercultural Biblical Exegesis in Africa. Holy Trinity Seminary Theological Studies 61(1\&2):291-326.

Loba-Mkole, Jean-Claude. (2008). Rise of Intercultural Biblical Exegesis in Africa. Holy Trinity Seminary Theological Studies 64(3):1347-1364. 
McArthur, Harvey K. (1966). The Quest Through the Centuries: The Search for the Historical Jesus. Philadelphia: Fortress Press.

Miller, Robert J. (2014). The Domain and Function of Epistemological Humility in Historical Jesus Studies. Journal for the Study of the Historical Jesus 12(1-2): 130-142.

Nolan, A.(1976). Jesus before Christianity: The gospel of liberation, David Philip, Cape Town.

Ntre, B.A.(2001). Africa in the New Testament. In: Getui, M.N.; Maluleke, T. and Ukpong, J.S.(eds.) Interpreting the New Testament in Africa. Nairobi: Acton Publishers, 68-82.

Obeng, E. (2001). Emerging Concerns for Biblical Scholarship in Ghana. In: Mary Getui, Tinyiko Maluleke, and Justin S.Ukpong (eds.) Interpreting the New Testament in Africa. Nairobi: Acton Publishers.

Okure, Teresa. (1993). Feminist Interpretation in Africa. In: E. S. Fiorenza (ed) Searching the Scriptures: A feminist Introduction. New York: Crossroads.

Okure, T. (2012). Historical Jesus Research in Global Cultural Context. In: Tom Holmén and Stanley E. Porter (eds) Handbook for the Study of the Historical Jesus Vol.1. Leiden: Brill, 953-984.

Ottuh, John A. (2014). Contextualization of Biblical Interpretation in Africa. International Journal of Research in Arts and Social Sciences 7 (2): 28-44.

Patte D. (1995). Ethics of Biblical Interpretation. Lousville: Westminister John Knox.

Perrin, Norman. (1967). Rediscovering the Teaching of Jesus. London: SCM, 39.

Reumann, John. (1989). Jesus and Christology. In: E.J. Epp and G.W. MacRae (eds) The New Testament and its Modern Interpreters. Atlanta: Scholars, 501-564.

Robinson, James M. (1959). A New Quest for the Historical Jesus. SBT 25. London: SCM.

Schweitzer, Don. (2004). A Theological Significance of the Quest for the Historical Jesus. International Journal of Theology 46(1\&2): 45-52. 
Ottuh: Posing the historical Jesus question...

Snodgrass, Klyne R. (2005). From Allegorizing to Allegorizing: A History of Interpretation of the Parables of Jesus. In: James D. G. Dunn, Scot McKnight (eds) The Historical Jesus in Recent Research. Eisenbrauns, 248-268.

Stuhlmacher, P. (1979). Historical Criticism and Theological Interpretation of the Bible. London: SPCK.

Telford, William R. (1994). Major Trends and Interpretive Issues in the Study of Jesus. In: Bruce Chilton and C.A. Evans (eds) Studying the Historical Jesus: Evaluations of the State of Current of Research. Leiden: Brill, 57-58.

Theissen, G. and Merz, A. (1998) The Historical Jesus: A Comprehensive Guide. Minneapolis: Fortress, 10-11.

Ukpong, J.S. (2000). Developments in Biblical Interpretation in Africa: Historical and Hermeneutical Directions. In: G. O.West and M. Dube (eds) The Bible in Africa: Transactions, Trajectories and Trends, Leiden: E.J. Brill.

Ukpong, J.S. (2008). Historical Jesus Research in Anglophone Africa, presented in the Department of Religious and Cultural Studies, University of Uyo, 1-14.

Van Aarde, A.G. (1999). Dekonstruksie van dogma: 'n Eietydse ondersoek na die spore van die leer van die twee nature van Jesus. HTS Teologiese Studies/Theological Studies 55(2\&3): 437-470.

Van Aarde, A.G. (2004). Postmoderne epistemologie en postkoloniale hermeneutiek. HTS Teologiese

Studies/Theological Studies 60(3): 1105-1112.

Van Voorst, Robert E. (2000). Jesus outside the New Testament: An Introduction to the Ancient Evidence, Studying the Historical Jesus. Grand Rapids, MI: Eerdmans, 6-16.

Varner, Will (1997). What is the Importance of the Dead Sea Scrolls? Associates for Biblical Research. http://www.christiananswers.net/q-abr/abr-a023.html.

Retrieved April 25, 2015.

Waweru, Humphrey. (2011). The Bible and African Culture: Mapping Transactional Inroads. Limuru, Kenya: Zapf Chancery Publishers Africa, 224pp.

Wells, George A. (2004). Can We Trust the New Testament? Thoughts on the Reliability of 
Early Christian Testimony. Chicago: Open Court.

West, Gerald. (2008). Biblical Hermeneutics in Africa. In: Parratt, John (ed) A reader in African theology, Revised edition, London:SPCK.http://www.chorastrangers.org/files/chora/we st2008_Parratt.pdf. Retrieved April 25, 2015

Williams, Rowan (1987). Arius: Heresy and Tradition. London: Darton, Longman and Todd.

Wright, N. T. (1996). Jesus and the Victory of God, in Christian Origins and the Question of God, vol. 2. Minneapolis, MN: Fortress Press. 